Agricultural Marketing Service

Dec 2013

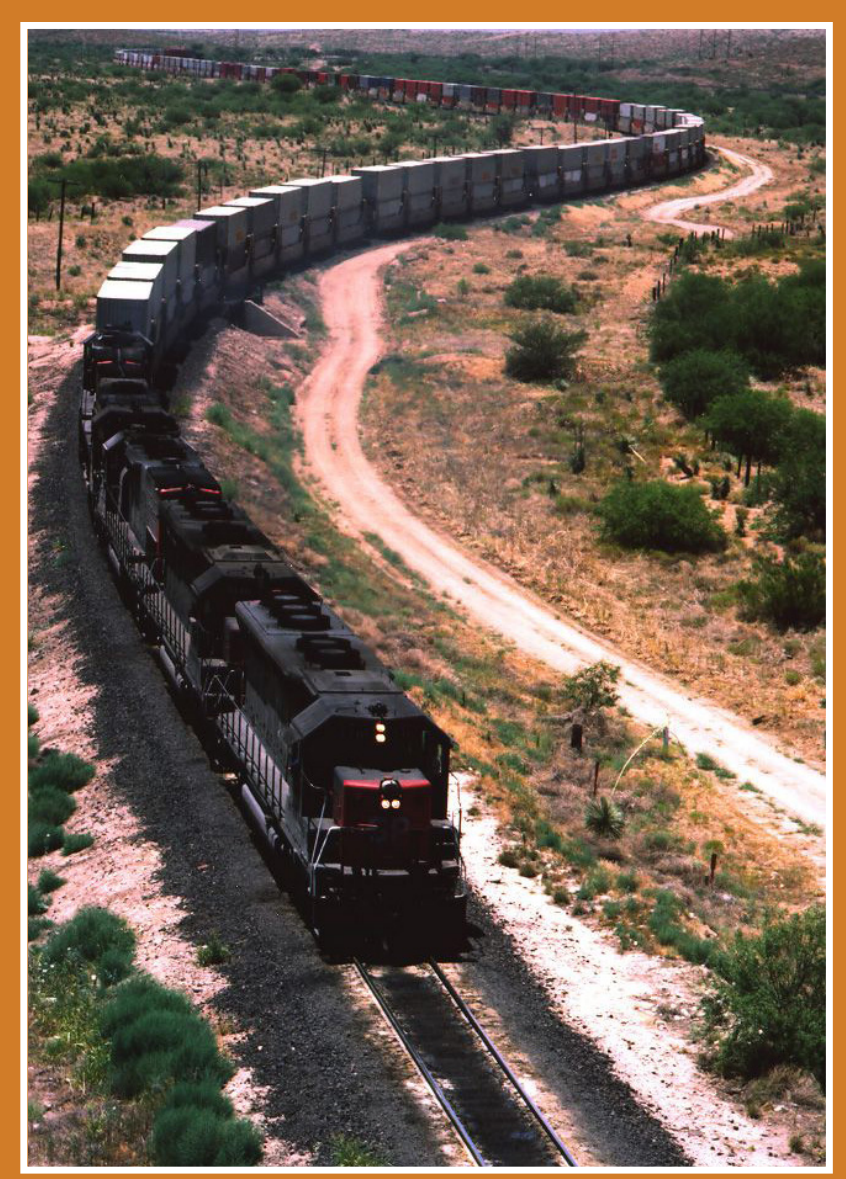

Source: World Shipping Council

\section{Rail's Loss of Grain Transportation Market Share}

Marvin Prater Adam Sparger Pierre Bahizi Daniel O’Neil, Jr.
The share of the grain and oilseed harvest moved by rail has been declining since 1980, when the Federal Motor Carrier Act and the Staggers Rail Act were passed. Large structural changes associated with these Acts affected the decline over the following two decades. Yet, even though the large structural changes had already taken place by 2000 , the rail market share of grain and oilseed transportation continued to decline. A State-level statistical model for 21 of the top grain-producing States (which produce 86.6 percent of all grain and oilseeds) investigated the major factors responsible for the decrease in the rail market share of grain and oilseed transportation from 2001 to 2010. Although not every factor affecting the rail market share of grain and oilseed transportation could be captured, 10 statistically significant factors were identified. Of these factors, three were the most important: the growth of ethanol production, the growth of biodiesel production, and increases in animal feeding.

The use of corn to produce ethanol has markedly reduced the rail market share in many States. Ethanol plants are usually located close to corn-producing areas, so trucks are used to haul corn to ethanol plants. Iowa, the leading ethanol-producing State, produced approximately 3.64 billion gallons of ethanol in 2010, up from 4.26 million gallons in 2001. This reduced its rail market share by approximately 20.9 percent over this time period.

In addition, biodiesel production has increased from 2 million gallons in 2000 to almost 1 billion gallons in 2010. As more soybeans were transported by truck to biodiesel refineries, this decreased the rail market share of soybeans for States such as Missouri. Missouri's rail market share decreased 6.8 percent as its biodiesel production increased by almost 48 million gallons.

The increased geographic concentration of animal feeding has resulted in feed grain hauls being interstate, which favor rail transportation; shorter haul movements within a State favor truck. In addition, the increased use of dried distillers grains with solubles and soymeal in feed rations has resulted in less grain and oilseeds being transported to animal feeding regions. The number of grain-consuming-animal units in Iowa increased by 15.2 million between 2001 and 2010, resulting in a decrease in its rail market share of 3.9 percent as more Iowa-produced grain was moved by truck to feeding locations.

The decline in the rail market share of national grain and oilseed transportation was not uniform across States; some States had increases in rail market share. Factors responsible for an increase in market share include railroads shipping more grain in larger shipments (over 50 carloads), increased grain exports, and increases in truck rates (as measured by the highway cost of diesel fuel) relative to rail rates. Crop production choices are also related to rail market share, with increased areas devoted to the production of wheat, cottonseeds, and flaxseed causing an increase in rail market share.

This is a summary of Rail Market Share of Grain and Oilseed Transportation, published by the Journal of the Transportation Research Forum in summer 2013.

Preferred Citation: Prater, Marvin, Adam Sparger, Pierre Bahizi, and Daniel O'Neil, Jr. Rail's Loss of Grain Transportation Market Share. U.S. Department of Agriculture, Agricultural Marketing Service, December 2013. Web <http://dx.doi.org/10.9752/ TS089.12-2013>

USDA is an equal opportunity provider and employer. 